\title{
Effect of Using New Technology Vehicles on the World's Environment and Petroleum Resources
}

\author{
Maen Al Rashdan', Mohammad Al Zubi", Mohamad Al Okour ${ }^{1}$ \\ 1 Mechanical Engineering Department, Al Hoson College, Al Balqa Applied University, Jordan \\ 2 Mechanical Engineering Department, Tafila Technical University, Jordan \\ * Corresponding author's e-mail: malzuby@ttu.edu.jo
}

\begin{abstract}
Nowadays, the trend towards the use of transportation technologies which are clean and less dependent on fossil fuel is highly increased. That is because of the fast depletion of oil reserves in the world. On the other hand, the growth of developing nations into industrialized ones will increase the demand on the energy sector, a large part of which is transportation. This development of the transportation sector will affect the environment as a result of greenhouse gases. In this paper, the use of several types of clean energy vehicles is demonstrated, compared with the ones utilizing classic internal combustion engine, with statistical demonstration and the energy conversion chain. The impact of hybrid vehicles on the petroleum reserves and consumption rates will also be discussed using some mathematical equations.
\end{abstract}

Keywords: clean energy vehicles, emissions, conversion chain, depletion time

\section{INTRODUCTION}

The rapid and highly accelerated demand on the energy sector in the developing world, occurring as a result of high economic growth rates, led a serious consideration of providing clean and sustainable energy alternatives to satisfy these needs, taking into account that the energy sector depends totally on the traditional crude oil and natural gas. On the other hand, the reserves of these sources are declining with time. A mathematical model was proposed to calculate the expected life of these reserves. The cost of exploring new fields has increased and will not satisfy the global demand from these resources. From an environmental point of view, the global climate changes - like the global warming and greenhouse gases effects, which results from $\mathrm{CO}_{2}$ emissions - make the world thinks about the uncontrolled use of fossil fuels. Because of the above-mentioned reasons, alternative energy sources must be developed.

The global interest in the environment and the rapid growth in the world population, increase the demand on petroleum sources for different uses. Figure 1 shows the relation between the world population and the fuel consumption. This increase of consumption affects the environment directly as a result of the emissions being delivered from burning these fuels in different ways. The energy consumption in 2016 was about $155 \cdot 10^{9}$ MWh [BP Statistical Review, 2017], with about 33432 million tons of $\mathrm{CO}_{2}$ released in the atmosphere to meet this energy demand, the increase in $\mathrm{CO}_{2}$ concentration causes global and regional climate changes, i.e. GHG cause environmental changes [Onn et al., 2017]. Out of this huge figure, about $90 \%$ is due to carbon emissions from the combustion of energy fuels [Environmental Protection Agency Report, 2017]. An estimate of the global population and related energy demand is shown in Figure 1 [Omer, 2008]

During the past century, global surface temperatures have increased at a rate of $0.2^{\circ} \mathrm{C}$ in the last two decades as a result of greenhouse gas emissions [Brutsaert, 2017]. Greenhouse gases are the gases in an atmosphere that absorb and emit radiation within the thermal infrared range 


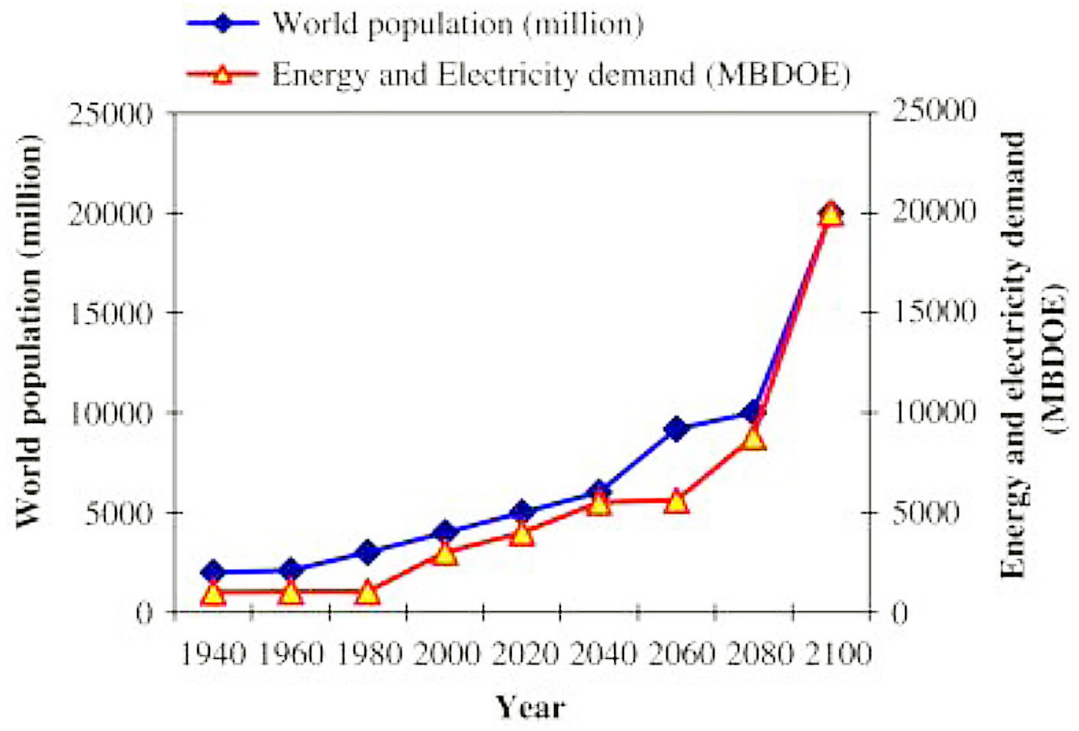

Figure 1. Annual and estimated world population and energy demand (millions of barrels per day of oil equivalent)

[EPA Report, 2017]. Burning of fossil fuels is one of the fundamental causes of the greenhouse effect. Figures 2 and 3 shows the global greenhouse gases by type and economic sector respectively in 2014 [Global Greenhouse Gas Emissions Data, 2014].

According to this problem, a rapid response from the industrial countries must be taken to avoid future increases in emission levels as their economies develop and populations grow, as the Kyoto Protocol provided. The Kyoto Protocol was adopted in 1997 as a result of the United Nations Framework Convention on Climate Change (UNFCCC) negotiations. It included the commitments to reduce the emission greenhouse gases (GHGs) by 5.2\% [Kuriyama and Abe, 2018]
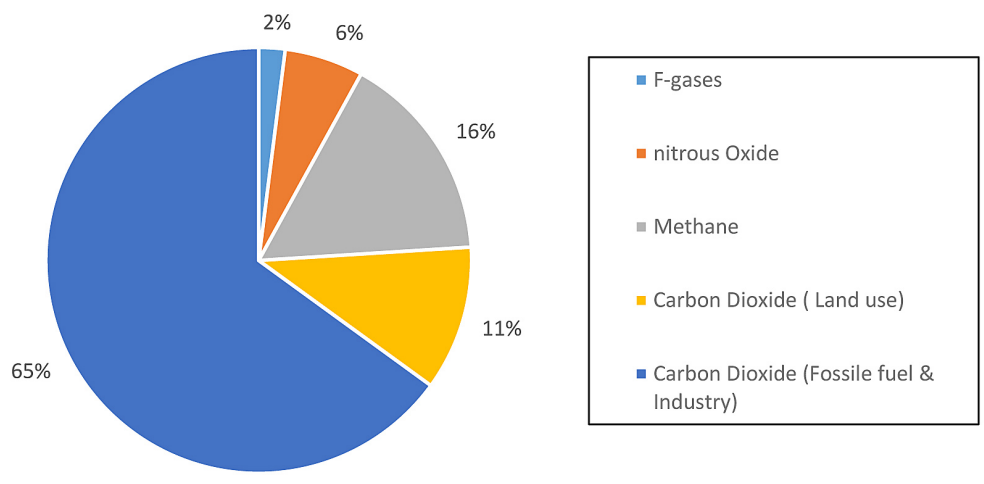

Figure 2. Greenhouse gases (GHG) by type
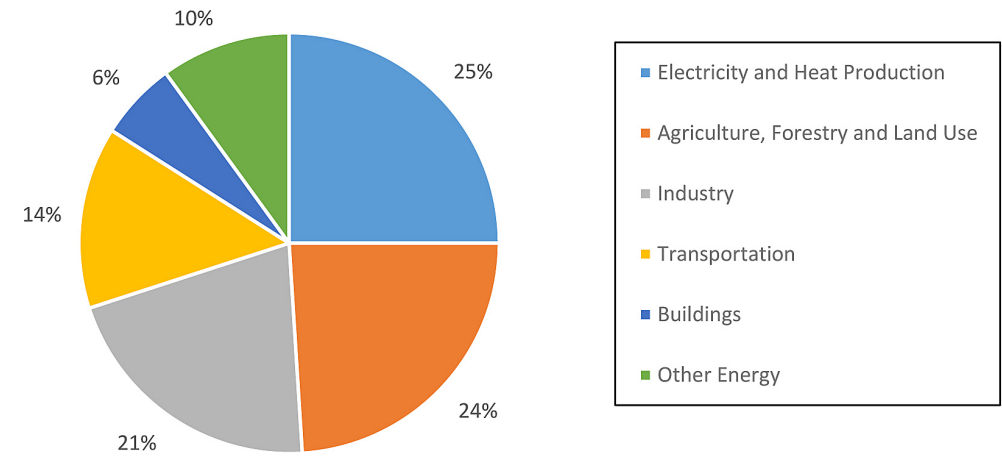

Figure 3. Greenhouse gases (GHG) by sector 


\section{ENERGY CONVERSION CHAIN}

Anytime we use energy in our daily life, we convert one form of it to another, for example, our cars convert chemical energy in the fuel to mechanical energy to move the car. This is an example of the Energy Conversion Chain [Evans, 2005] in which a primary energy source is converted to a final form through a chain of conversions (Figure 4). Considering any system in the world, the total chain must be considered because each step means money.

As can be seen from the graph, the chain consists of an energy source which undergoes a processing to produce an energy carrier that can be stored, then delivered to the end user; two emissions are observed in the processing and the end use stages. As an example of this process, internal combustion engine is considered where the emissions are carbon monoxide, carbon dioxide, unburned hydrocarbons, and nitrogen oxides, these emissions are released in the refinery process (energy carrier) and the combustion process (end use conversion). Thus, we can conclude that using a clean primary energy source will lead to reducing emissions and improving the environment.

\section{MATHEMATICAL MODLING OF WORLD FUEL RESOURCES}

Over a long period of time, the rate of oil products consumption to the oil reserves discovery is almost constant [Difiglio, 2014].

A mathematical model can be used to predict the future use of oil reserves. Figure 5 below demonstrates the annual and cumulative oil consumption from 1980-2015 [www.eia.gov, 2017]. In the mathematical model, the following abbreviations will be used:

- $A_{o}$ :The annual consumption in 1990.

- $G_{b}$ : Fuel consumption In giga barrels.

- $A(t)$ : Annual consumption amount at year $\mathrm{x}$.

- $Y$ : Percent increase in consumption per year $(1.6 \%)$.

- $x_{0}$ : The year 1990

- $\quad x$ : Any year after 1990

- $D(t)$ : The discovered world oil reserves in $\mathrm{G}_{\mathrm{b}}$

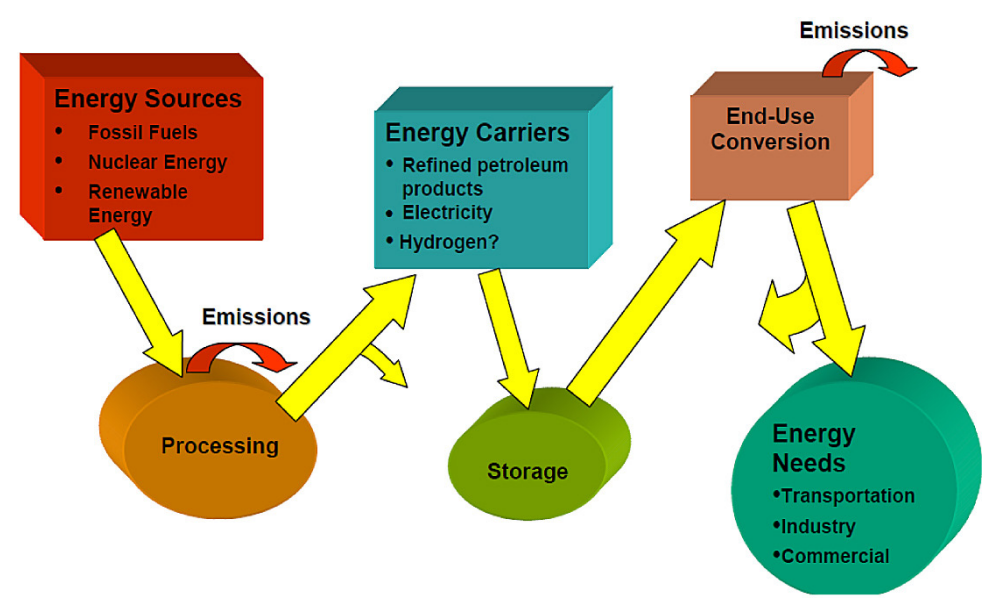

Figure 4. The energy conversion chain

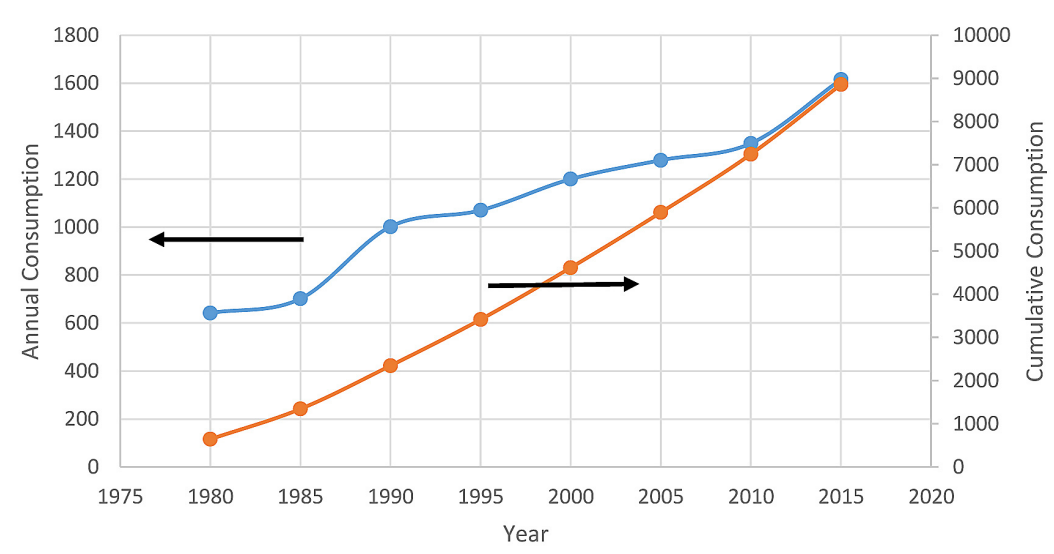

Figure 5. Global annual and cumulative consumption 
From the Figure 5, it can be seen that in 1990 the annual consumption was $36.5 \mathrm{G}_{\mathrm{b}}$, while in the year 2015 it was $58.4 \mathrm{G}_{\mathrm{b}}$, the annual increase in consumption can be approximated by averaging the data from the curve which is not linear due to the increase in petroleum users. From the curve, this annual increase is about $1.6 \%$ yearly [Ehsani and Emadi, 2009].

Therefore, the generalized formula for annual consumption becomes:

$$
\mathrm{A}(\mathrm{t})=\mathrm{A}_{0}(1+\mathrm{Y})_{0}^{(\mathrm{x}-\mathrm{x})}
$$

From the equation presented above, we can calculate the annual consumption at any year. In order to obtain a formula for the estimated oil reserves in the next years, it was discovered from the empirical data [International Energy Outlook, 2017] that the known reserves capacity in the years 1990 and 2015 were 1600 and 1850 , respectively. Using this data, the estimated world oil reserve supply formula in the future is:

$$
D(x)=12(x-2015)+1850
$$

From the empirical data it can be seen that the annual discovery rate is 12 which appears in the above equation. Another equation for the international consumption derived from the previous data can be:

$$
\operatorname{Acon}(x)=30 \int_{0}^{x-2015} 1.016^{x} d x+900
$$

It is obvious that when $\mathrm{A}_{\text {con }}(\mathrm{x})$ exceeds $\mathrm{D}(\mathrm{x})$, the consumption will exceed the discovered reserves, so the world must look for new resources of fuel.

In order to determine the expected life time of the fuel supply, a plot of the remaining reserves, the known and expected cumulative consumption oil reserve together are shown in Figure 6. From the graph above, the expected time for oil depletion is 2048 .

In order to delay this depletion time, either doubling the discovery rate or decreasing consumption are the solutions. From equation (2) above, if the yearly discovery is doubled from 12 to 24 , the expected depletion date will be 2058 ; this can be done mathematically be equating equations (2) and (3), and solving for (x), so an increase of 10 years is gained. Actually, this is impossible, so decreasing consumption seems to be the solution by using new technology transportations like fuel cell and electric vehicles.

Returning back to equation (1), by decreasing the growth rate of consumption (Y), to $0.9 \%$, the same fuel lifetime can be achieved, so under normal discovery conditions, decreasing the annual consumption rate by about $35 \%$ will lead to oil depletion in 2058, as shown in Figure 7.

\section{ALTERNATIVE FUELS FOR TRANSPOR- TATION AND NEW TRANSPORTATION TECHNOLOGIES}

Alternative fuel vehicles are called clean cars from cradle to grave [Brennan and Barder, 2016]. The fuels used in the transportation sector all over the world can be both fossil and nonfossil fuels. According to the first one which is liquid petroleum, it has certain advantages, like high energy density [Ferguson and Kirkpatrick, 2016], secondly it is easy to transport and store. On the other hand, this type of fuel has disadvantages too, as it is a non-renewable resource; thus, it will be depleted after a period of time as

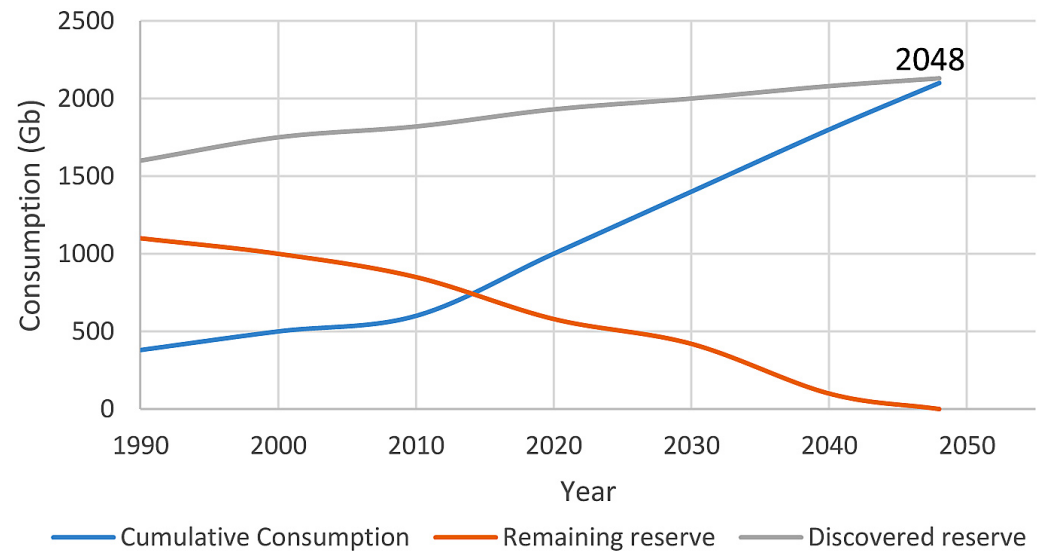

Figure 6. The year of oil end supply will be 2048 


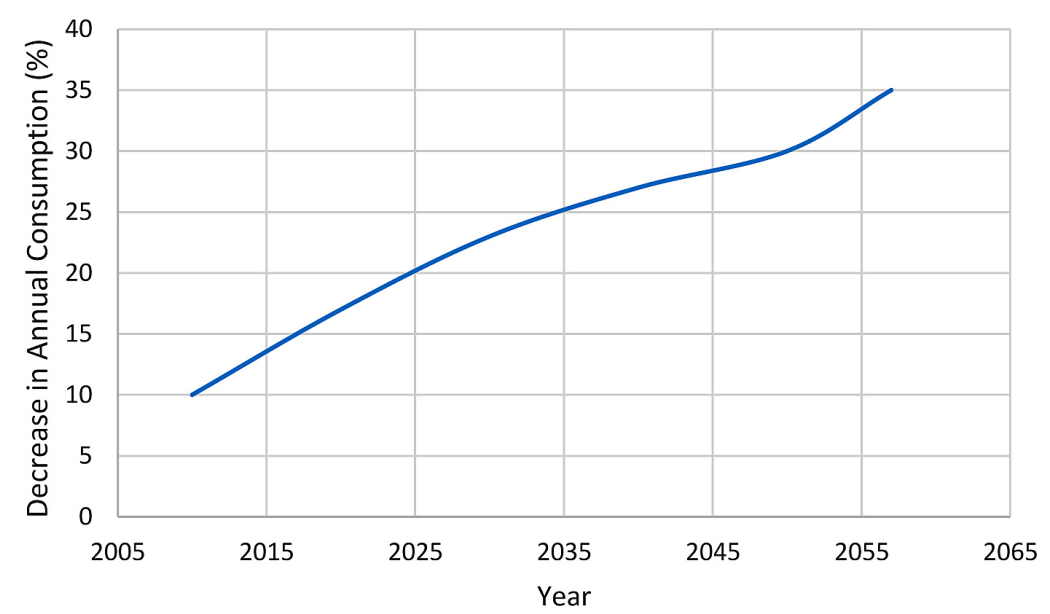

Figure 7. Decreasing annual consumption rate to reach the expected depletion year 2058

shown previously. Secondly it is hazardous to the environment because of its hard emissions ( $\mathrm{NO}_{\mathrm{x}}$, $\mathrm{CO}, \mathrm{CO}_{2}$, unburned $\mathrm{HCs}$ ). Now, as can be seen from the energy conversion chain, emissions can be controlled in the processing stage and/or in the end-use conversion stage. If the energy source is fossil fuel and the energy carrier is an electrical battery for a vehicle, the net reduction in emissions is low. On the other hand, if the energy source and the energy carrier are renewables and electricity respectively, the aim will be achieved.

According to the new transportation, four vehicle technologies will be discussed here, including: fuel cell vehicles, battery electric vehicles, hybrid-electric vehicles, and finally the plug-in hybrids, with some statistical data from up-todate resources.

The use of hydrogen as an energy carrier in the fuel cell of vehicles instead of internal combustion engine has been introduced in the last few years. The fuel cell efficiency is about $51 \%$, compared with 39\% for internal combustion engines [Ferguson and Kirkpatrick, 2016], while the price of this technology is 1.5 of that characterizing the internal combustion engine [Steinberger-Wilckens and Lehnert, 2010].

If we assume that the primary energy source is a renewable source (photovoltaic, wind, etc), then there would be no production of emissions in the energy conversion chain. The principle of fuel cell [Steinberger-Wilckens and Lehnert, 2010] is basically the use of electrical current produced from photovoltaic cells for electrolysis of water to produce hydrogen, then a compressor is used to compress hydrogen to liquid in a storage tank on board the vehicle [Haldeman, 2012]. This compressed hydrogen will be used to operate the fuel cell to produce electricity which is used to supply an electric motor, which is finally used to produce mechanical power to drive the vehicle. Thus, chemical energy is converted to electrical energy. The fuel cell vehicle schematic is shown in Figure 8.

One major disadvantage of using fuel cell vehicles is the storage tank on board the vehicle, which is similar to the fuel tank in the internal combustion engine vehicles. At the ambient temperature and pressure, hydrogen is a gas, so it must be compressed to a temperature of about $-250^{\circ} \mathrm{C}$ and a pressure of about 350 bar to be a liquid [Haldeman, 2012]. This requires heavy storage cylinders, so the overall vehicle weight and volume will be high. This disadvantage of the fuel cell vehicles makes its marketing so difficult.

In order to see the effect of fuel cell technology on the annual fuel consumption, this technology has penetrated the market by the year 2015,

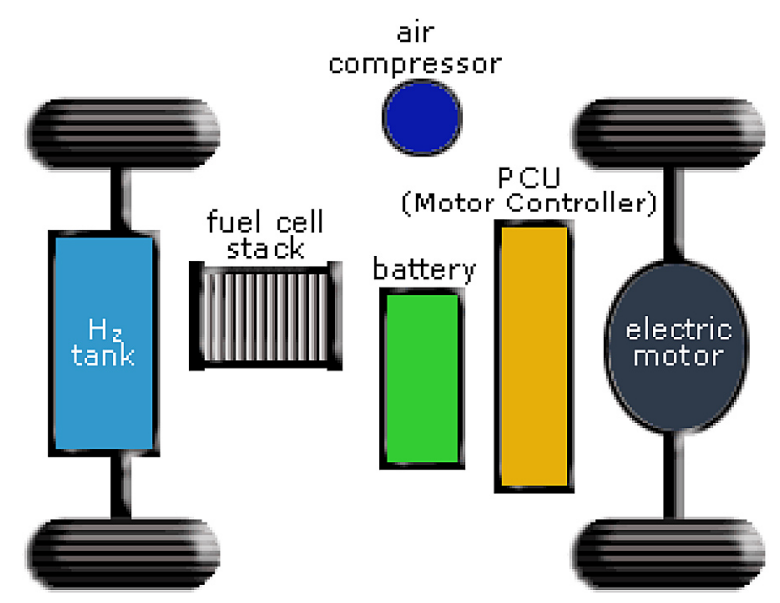

Figure 8. Fuel Cell Vehicle Energy Chain [National Renewable Energy Laboratory] 


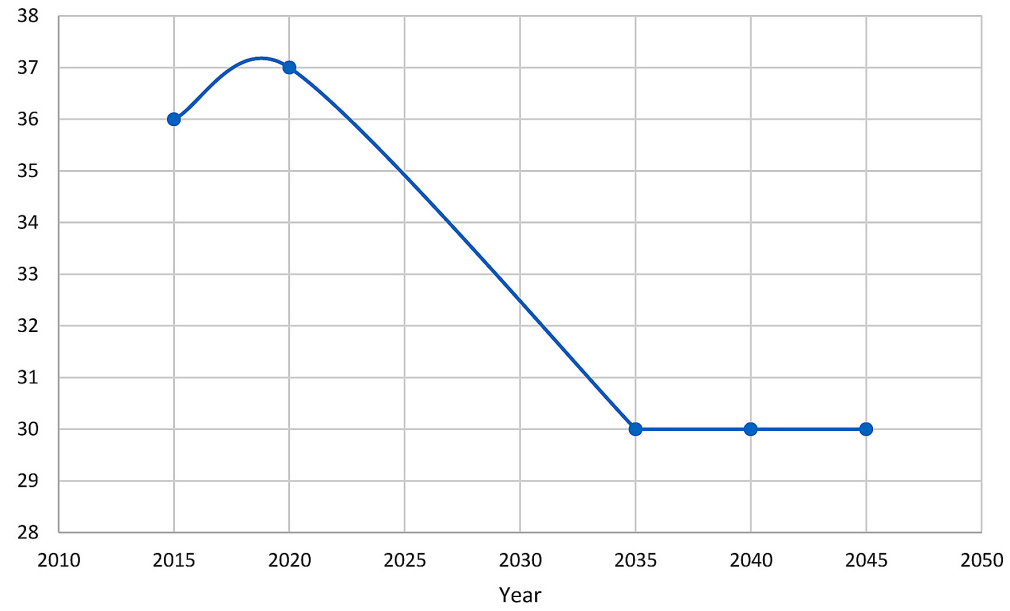

Figure 9. Positive effect of fuel cell on fuel consumption

and it is expected that it will saturate the market by $2035,19 \%$ savings in fuel consumption will be achieved, as shown in Figure 9.

The second technology is the battery electric vehicle (BEV). Here, the storage tank is the battery.

In this technology, the energy is stored as electricity, compared with fuel cell in which energy is stored as hydrogen. The electricity stored in the battery can be used to drive the electric vehicle. From the point of view of energy conversion chain, the main difference between the two types is that the hydrogen production, storage, and fuel cell package in the fuel cell vehicle have been replaced by a battery as a storage device in the BEV. This technology is shown in Figure 10.

Many advantages are related to the use of BEVs. Firstly it shows a positive performance in GHG emissions reduction (ranging from $30 \%$ to $80 \%$ ) when compared with gasoline internal combustion engine vehicles (ICEVs) [Tianduo et al., 2018].

Secondly, according to International Energy Agency (IEA), it has been estimated that BEV's will represent $35 \%$ of new vehicles sales by 2035 and that will limit the climate change to less than $2^{\circ} \mathrm{C}$ [Hasan, 2017]. Moreover, it is expected that in 2030, a reduction of 72 Mton $\mathrm{CO}_{2}$ emission will be achieved due to the use of this technology [Kampman et al., 2011].

Thirdly, Mark Fields - the President and CEO of Ford - expects that within 15 years, the number of electric vehicles will exceed the count of internal combustion engine (ICE) vehicles [Economist, 2017].

Conventional internal combustion engine vehicles (ICEVs) would produce approximately $180 \mathrm{~g}$ of $\mathrm{CO}_{2}$ emission per kilometer, a hybrid petrol-electric vehicles (HEVs) with the same setting would produce $80 \mathrm{~g}$ of $\mathrm{CO}_{2}$ emission per kilometer [Onn et al., 2017].

HEVs can improve the fuel efficiency by about $40 \%$. Therefore, when a HEV is driven to replace a gasoline ICEV for a year, the emissions of $\mathrm{CO}_{2}$, $\mathrm{PM}_{10}, \mathrm{NO}_{x}$, and $\mathrm{SO}_{2}$ can be reduced by 1023 $\mathrm{kg}, 189 \mathrm{~kg}, 832 \mathrm{~kg}$, and $274 \mathrm{~kg}$, respectively, as shown in Figure 11 [Ya Wu and Li Zhang, 2017].

Electric vehicles are able to use the storage energy in the batteries for about 100 miles. These batteries can be recharged at night or when the car is not in use. Its low price, compact size, and light weight compared to a fuel cell vehicle, make this kind of vehicles preferable to consumers. In 2015,

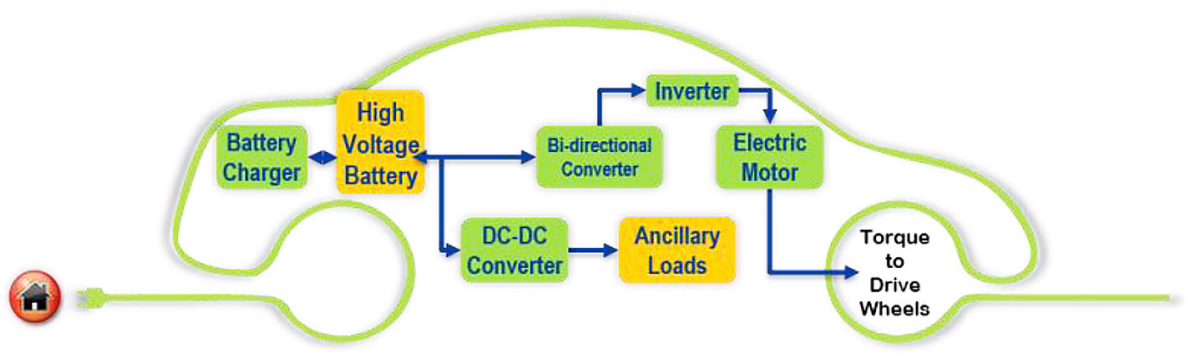

Figure 10. Electric Vehicle with main parts [http://www.autocaat.org] 


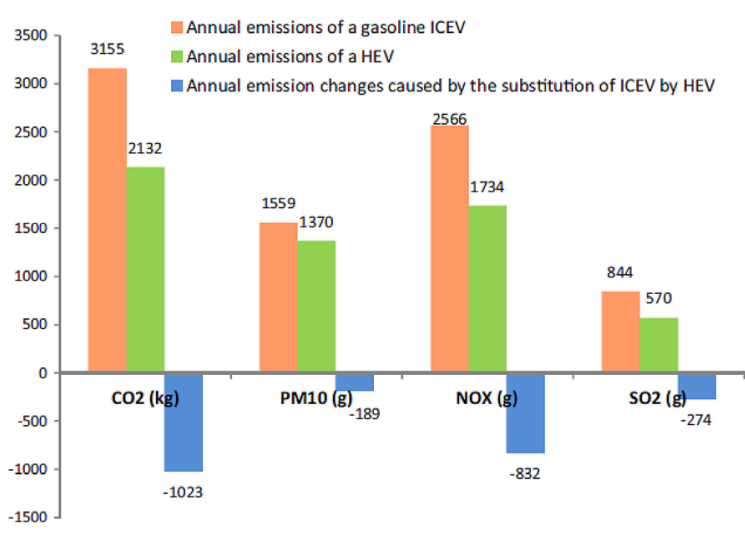

Figure 11. Life-cycle GHG emissions of vehicles per unit distance travelled

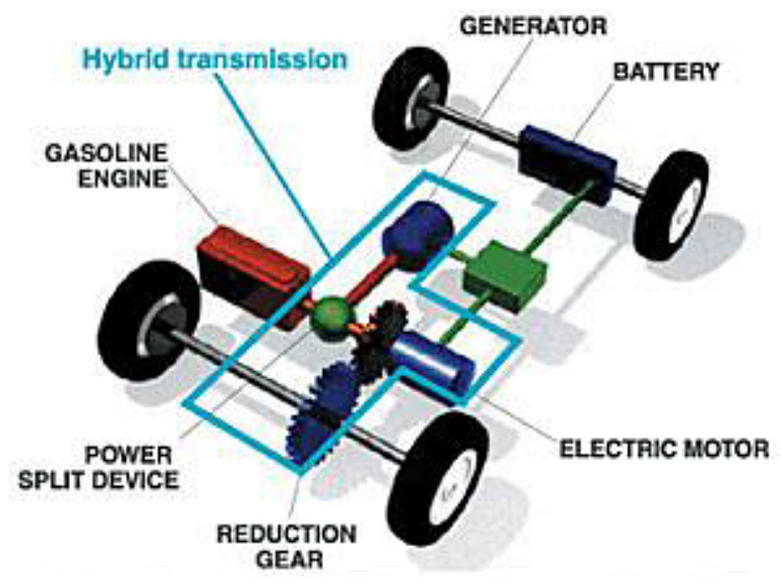

Figure 12. HEV configuration

the electric vehicle produced 105,054 pounds of greenhouse gas emissions $\left(\mathrm{CO}_{2}-\right.$ equivalents $)$ over a full vehicle lifetime, whereas the equivalent internal combustion engine vehicles produced 136,521 pounds of greenhouse gas emissions, with $23 \%$ advantage in global warming potential for the BEV [Brennan and Barder 2016].

The third technology is called the hybridelectric vehicle (HEV). As shown in Figure 12, it involves an electric motor with a small internal combustion engine and a high quality controller. The controller decides when to operate the engine and when to shut it off to achieve the optimum fuel consumption. For instance, in cities where the low speed is demanded, the engine is shut down while the battery-powered electric motor propels the car. Regenerative braking is an advantage of these vehicles, which enables to take advantage from decelerating the car and the heat dissipated from the brake system. The energy is transmitted to a generator, which is used to charge the battery. It has been found that the fuel efficiency of this type is about $50 \%$ greater than in the case of conventional internal combustion engine vehicles. Conventional internal combustion engine vehicles (ICEVs) would produce approximately $180 \mathrm{~g}$ of $\mathrm{CO}_{2}$ emission per kilometer, a hybrid petrol-electric vehicles (HEVs) with the same setting would produce $80 \mathrm{~g}$ of $\mathrm{CO}_{2}$ emission per kilometer [Onn et al., 2017].

The fourth technology which is considered constitutes a new invention of hybrid vehicles, known as plug-in hybrids. It mixes the electric vehicle and hybrid vehicle technologies. The battery pack is large enough so that it can be charged by plugging it into the electric grid, so this vehicle can operate completely as an electrical vehicle for about 70-100 miles. A small internal combustion engine is used to charge the battery when the afore-mentioned distance is exceeded or more power is demanded according to a controller used for this purpose. In considering the energy conversion chain for this type, and taking into account that the primary energy source is sustainable, the emissions will be decreased dramatically, so it becomes more preferable for drivers, as it has low levels of noise, and the ex-

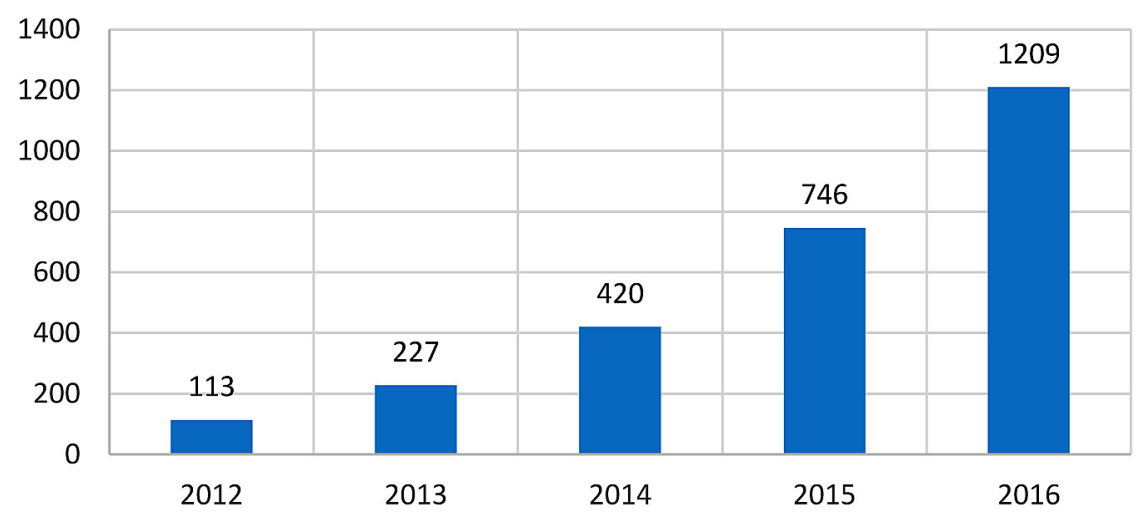

Figure 13. BEVs worldwide (2012-2016) 


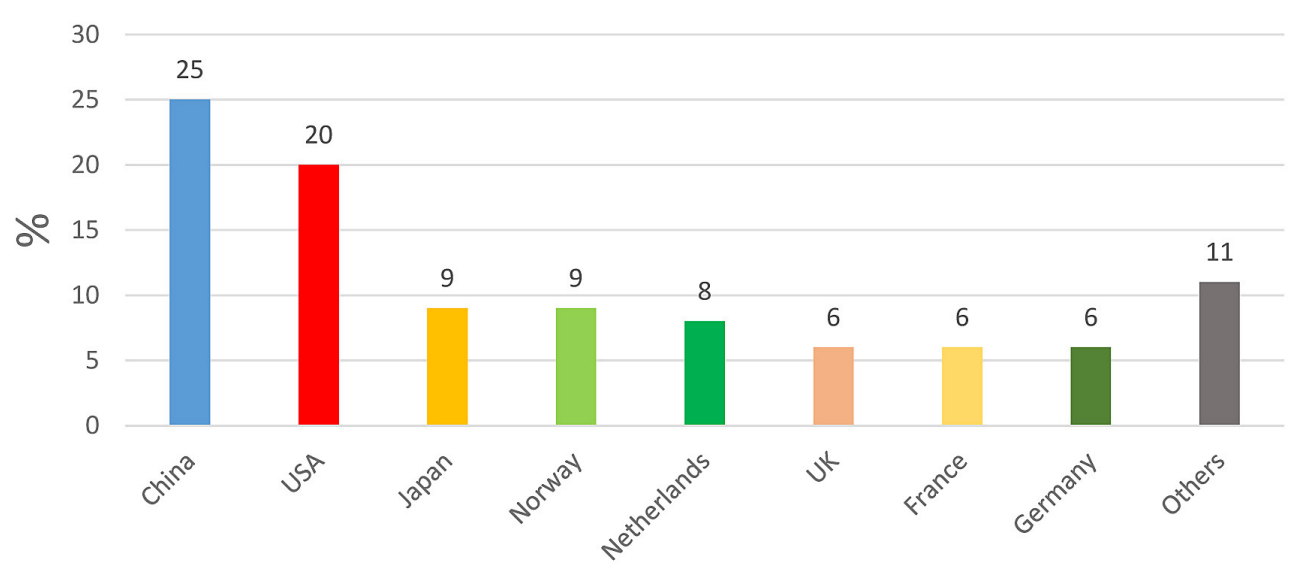

Figure 14. Leading countries in the world using EVs

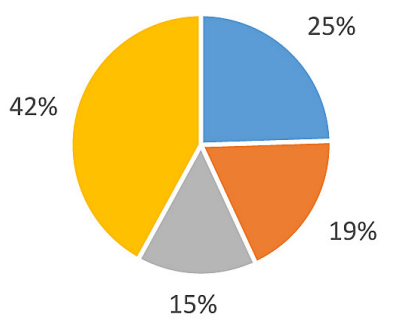

Figure 15. Top Selling Models in Europe (2014)

cellent fuel consumption, finally a good friend to the environment due to low emissions.

In order to show the benefits of using these new technologies all over the world, some statistical graphs are included here, which represent the increasing number of BEVs in the market from (2012-2016) [www.statista.com] with an increase of about $90 \%$ in four years (Figure 13). In Figure 14, the leading countries using BEVs worldwide are shown; China is the highest one due to its huge population and tendency to reduce pollution. Figure 15 shows the top 3 selling models in Europe in 2014; as can be seen, Nissan Leaf occupies around $25 \%$ due to its compact shape and because it is suitable for use by families [https://cleantechnica.com].

\section{CONCLUSION}

In this paper, it was shown that the expected time for oil depletion may be 2048. Thus, the decision makers all over the world are seriously considering switching towards renewable energy sources to solve the transportation sector, which consumes around $28 \%$ of the fossil fuels and participates in the global warming problems due to emissions. The energy conversion chain was discussed and it must be considered to compare the energy end-use for sustainability. The use of different types of new technology vehicles showed that it will participate in delaying the depletion of oil resources as well as reduce the global emissions, which will positively affect the environment and coincide with the international regulations like the Kyoto protocol.

\section{REFERENCES}

1. BP Statistical Review of World Energy. BP Company, 2017.

2. Brennan J.W., Barder T.E. 2016. Battery Electric Vehicles vs. Internal Combustion Engine Vehicles. A United States-Based Comprehensive Assessment. Available: http://www.adlittle.us/uploads/tx_extthoughtleadership/ADL_BEVs_vs_ICEVs_FINAL_ November_292016.pdf. [Accessed: Aug. 7, 2018].

3. Brutsaert W. 2017. Global land surface evaporation trend during the past half century: Corroboration by Clausius-Clapeyron scalling. Advances in Water Resources, 106, August, 3-5.

4. $\mathrm{CO} 2$ Emissions from Fuel Combustion Report, 2016. International Energy Agency.

5. Difiglio C. 2014. Oil, economic growth and strategic petroleum stocks. Energy Strategy Reviews, 5, December, 48-58.

6. Ehsani M., Emadi Y.A., 2009. Modern Electric, Hybrid Electric, and Fuel Cell Vehicles: Fundamentals, Theory, and Design, Second Edition.

7. Economist, 2017. Electric Cars: Volts Wagons. February 18.

8. Evans R.L. 2005. Reducing Global Warming with innovative transportation technology. SAE Technical Paper Series.

9. Ferguson C.R., Kirkpatrick A.T., 2013. Internal 
Combustion Engines: Applied Thermosciences. Third Edition, Wiley.

10. Haldeman J., 2012. Automotive Fuel and Emission Control Systems. Third Edition, Pearson.

11. Hasan S., 2017. Impact on crude oil demand by electric vehicles in China - Adopting measures similar to Norwegian EV policy. Master thesis.

12. https://cleantechnica.com/2017/08/19/top-electriccar-countries-charts [Accessed: Aug. 7, 2018].

13. https://www.statista.com/statistics/270603/worldwide-number-of-hybrid-and-electric-vehiclessince-2009 [Accessed: Aug. 7, 2018].

14. Incekara C.O., Ougulata S.N. 2017. Turkey's energy planning considering global environmental concerns. Ecological Engineering, 102, May, 589-595.

15. Global Greenhouse Gas Emissions Data, 2014. Intergovernmental Panel on Climate Change.

16. International Energy Outlook, 2017. US Department of Energy.

17. Kampman B., van Essen H., Braat W., et al., 2011. Impacts of Electric Vehicles - Deliverable 5, Impact Analysis For Market Uptake Scenarios and Policy Implications. ICF International. Ecologic Institute. Delft.

18. Kuriyama A., Abe N. 2018. Ex-post assessment of the Kyoto Protocol-quantification of $\mathrm{CO} 2$ mitigation impact in both Annex B and non-Anex B countries. Applied Energy, 220, June, 286-295.
19. O’Hayre R., Suk-Won Cha, Prinz F.B., Colella W., 2016. Fuel cell Fundamentals. Third Edition, Wiley.

20. Omer A.M. 2008. Energy, environment and sustainable development. Renewable and Sustainable Energy Reviews, 12, 2265-2300.

21. Onn C.C., et al., 2017. Greenhouse gas emissions associated with electric vehicle charging: The impact of electricity generation mix in a developing country. Transportation Research Part D. Available: http://dx.doi.org/10.1016/j.trd.2017.06.018 [Accessed: Aug. 7, 2018].

22. Environmental Protection Agency Report, 2017. Overview of Greenhouse Gases. United States.

23. Steinberger-Wilckens R., Lehnert W., 2010. Innovations in Fuel Cell Technologies. RSC Energy and Environment Series, No. 2.

24. Tianduo P., Xunmin O., Xiaoyu Y., 2018. Development and application of an electric vehicles lifecycle energy consumption and greenhouse gas emissions analysis model. Chemical Engineering Research and Design, 131, 699-708.

25. United States Energy Information Administration, 2017.

26. Ya Wu, Li Zhang, 2017. Can the development of electric vehicles reduce the emission of air pollutants and greenhouse gases in developing countries? Transportation Research Part D, 51, 129-145. 